\title{
Students' Involvement in EFL Online Classroom during the Covid-19 Pandemic Era
}

\author{
Idham Syahputra \\ Faculty of Education and Teacher Training, \\ UIN Sultan Syarif Kasim Riau \\ Nur Isnani \\ Universitas Sarjanawiyata Tamansiswa Yogyakarta \\ noorisna6@gmail.com
}

\begin{abstract}
According to Norziani Dahalan, (2012) students' involvement is important in online classes. When students communicate verbally with teachers or with friends, their abilities will automatically develop. However, in online classes the researcher found that students were passive and didn't want to calculate their progress, they would be slower. Therefore, this study aims to see how the students' involvement in EFL online classroom during Covid-19 Pandemic at State Senior High School 1 Bengkalis with the hope that teachers can try to overcome it. This type of research is descriptive qualitative research. To measure the data, researchers used observation, video documentation, and interviews. The data analysis technique used in this research is to use qualitative data analysis techniques developed by Miles, (2019) there are includes three activities, namely: data reduction, data presentation, concluding, or levers. The results of this study are: First, students' involvement with the teacher is passive. Second, students' involvement with other students. Students can interact with their classmates in the online learning process even though the response is very time-consuming because the teacher or student's internet connection network is sometimes bad and interferes with the learning process. Third, students' involvement with the material. The involvement of English students with learning materials at SMA N 1 can be said to be good. Because the English teacher teaches well like how he does face-to-face learning in class. The difference is, teacher uses an online application.
\end{abstract}

\section{Keywords: Students' Involvement, EFL Online Classroom, Covid-19 Pandemic}

\section{Introduction}

At this time, the world was shocked by the existence of a deadly virus that can attack anyone, called the Covid-19 pandemic (Ahsani, 2020). The Covid-19 pandemic is a threat to everyone in carrying out their daily activities, including in the field of education (Ahsani, 2020). This is in line with Government Regulation Number 21 of
2020 concerning large-scale social restrictions to accelerate the handling of Covid-19 which results in restrictions on various activities including schools (Euis Kurniati, 2020).

The government in Indonesia issued several policies to stop the spread of Covid-19, one of which is diverting face-to-face learning in schools into distance learning at home or commonly 
known as online (Haerudin et al., 2020). Online learning is not easy to do, it differs almost 80 degrees from face-toface learning (Winaya, 2020). he most basic difference is that students cannot interact directly with the teacher so that communication is very limited (Teguh, 2015).

However, on the other hand, online learning certainly has advantages and disadvantages. The advantages of online learning include that students are more flexible in learning, do not have to be on time, the place can be conditioned depending on the situation and conditions, and students are freer to determine or find their learning resources by accessing the internet. Besides, the disadvantages are that students cannot socialize with other students and their teachers in real terms, so it will affect students' emotions and this is what causes EFL students' classroom involvement become disturbed in the process of teaching and learning (Naserly, 2020).

EFL students' classroom involvement is a problem that usually occurs in the teaching and learning process. Especially, in Teaching and Learning English as a Foreign Language, the students tend to be not participating in English online classroom. Student involvement is defined as the effort students devote to activities that are focused on education. Involvement is developed through interaction. The factors centered on the student's interaction, i.e. "Students interaction in online learning environments has implications on learner engagement and collaboration (Inês Messias, 2015). Students' involvement and participation in the online classroom is important to improve students' abilities. Students' verbal communication is evidence of their good performance in English. If there is no student participation frequently prevents the students from making progress and achieving the outcome intended for the course.

As regarded (Norziani Dahalan, 2012) students' involvement and participation are important in the online classroom. When the students make oral communication with the teacher or among peers, they will automatically develop their ability. But, when they are passive and do not want to participate, they will make slower progress. The goal of teaching and learning a language is for the students able to use the language in communication inside and outside the classroom (Koran, 2015). Means that the students learning English for their communication purpose. In fact, in the online classrooms the students reluctant to participate in classroom activities. This kind of reluctance makes the students lose their motivation to learn the language.

State Senior High School 1 Bengkalis is located on Arif Rahman Hakim Street Bengkalis District, Bengkalis Regency. State Senior High School 2 Bengkalis uses thirteen curriculum (K13). This school provides an English subject for the students. According to the thirteen curriculum (PERMENDIKBUD, 2016) the students are expected to be active in the teaching and learning process. The teaching and learning process is student-centered, the student enthusiasm in learning, motivated, interested, creative, initiative, inspired, innovated, and independent.

According to the researcher's preliminary study in State Senior High School 1 Bengkalis, some of the students still have problems in learning English especially in student involvement in the process of teaching and learning. Based on documentation 
video observation, the writer has seen that for real that some of the students do not participate and passive in the online classroom, students have many difficulties learning. Then the writers concluded from the results of the initial non-cognitive diagnosis of online learning to students in XI IPS 1 and XI IPS 2 in the online class, and the writer concludes this is because Feed, his unreasonable attitudes such as indifference to lessons, hard to understand the lesson, slow in doing study tasks, and always lag in doing questions. They tend to be silent and quiet in the learning process. The participation of the students is not the same as the expectation of the thirteen curriculum (K13).

At this time, the world was shocked by the existence of a deadly virus that can attack anyone, called the Covid-19 pandemic (Ahsani, 2020). The Covid-19 pandemic is a threat to everyone in carrying out their daily activities, including in the field of education (Ahsani, 2020). This is in line with Government Regulation Number 21 of 2020 concerning large-scale social restrictions to accelerate the handling of Covid-19 which results in restrictions on various activities including schools (Euis Kurniati, 2020).

The government in Indonesia issued several policies to stop the spread of Covid-19, one of which is diverting face-to-face learning in schools into distance learning at home or commonly known as online (Haerudin et al., 2020). Online learning is not easy to do, it differs almost 80 degrees from face-toface learning (Winaya, 2020). he most basic difference is that students cannot interact directly with the teacher so that communication is very limited (Teguh, 2015).

However, on the other hand, online learning certainly has advantages and disadvantages. The advantages of online learning include that students are more flexible in learning, do not have to be on time, the place can be conditioned depending on the situation and conditions, and students are freer to determine or find their learning resources by accessing the internet. Besides, the disadvantages are that students cannot socialize with other students and their teachers in real terms, so it will affect students' emotions and this is what causes EFL students' classroom involvement become disturbed in the process of teaching and learning (Naserly, 2020).

EFL students' classroom involvement is a problem that usually occurs in the teaching and learning process. Especially, in Teaching and Learning English as a Foreign Language, the students tend to be not participating in English online classroom. Student involvement is defined as the effort students devote to activities that are focused on education. Involvement is developed through interaction. The factors centered on the student's interaction, i.e. "Students interaction in online learning environments has implications on learner engagement and collaboration (Inês Messias, 2015). Students' involvement and participation in the online classroom is important to improve students' abilities. Students' verbal communication is evidence of their good performance in English. If there is no student participation frequently prevents the students from making progress and achieving the outcome intended for the course.

As regarded (Norziani Dahalan, 2012) students' involvement and participation are important in the online classroom. When the students make oral communication with the teacher or among peers, they will automatically 
develop their ability. But, when they are passive and do not want to participate, they will make slower progress. The goal of teaching and learning a language is for the students able to use the language in communication inside and outside the classroom (Koran, 2015). Means that the students learning English for their communication purpose. In fact, in the online classrooms the students reluctant to participate in classroom activities. This kind of reluctance makes the students lose their motivation to learn the language.

State Senior High School 1 Bengkalis is located on Arif Rahman Hakim Street Bengkalis District, Bengkalis Regency. State Senior High School 1 Bengkalis uses thirteen curriculum (K13). This school provides an English subject for the students. According to the thirteen curriculum (PERMENDIKBUD, 2016) the students are expected to be active in the teaching and learning process. The teaching and learning process is student-centered, the student enthusiasm in learning, motivated, interested, creative, initiative, inspired, innovated, and independent.

According to the reseacrher's preliminary study in State Senior High School 1 Bengkalis, some of the students still have problems in learning English especially in student involvement in the process of teaching and learning. Based on documentation video observation, the writer has seen that for real that some of the students do not participate and passive in the online classroom, students have many difficulties learning. Then the writers concluded from the results of the initial non-cognitive diagnosis of online learning to students in XI IPS 1 and XI IPS 2 in the online class, and the writer concludes this is because Feed, his unreasonable attitudes such as indifference to lessons, hard to understand the lesson, slow in doing study tasks, and always lag in doing questions. They tend to be silent and quiet in the learning process. The participation of the students is not the same as the expectation of the thirteen curriculum (K13). The study focuses on the problems of A Study on Students' Involvement in EFL Online Classroom during the Covid-19 Pandemic at Eleventh Grade of State Senior High School 1 Bengkalis. The research question is what are the forms of students' involvement in the online classroom during the covid-19 pandemic at the eleventh grade of state senior high school 1 Bengkalis?

\section{A. The 2013 Curriculum Standard Learning Model}

One of the government's efforts to improve the quality of national education Indonesia is to establish national education standards contained in Regulation No. 19 in 2005. The national educational standards include: a) Competency standards of graduates, b) Standard content, c) Process standards, d) Standard assessment, e) Educator and education standards, f) Standard infrastructure, g) Standard of financing and management.

With the national education standards that the direction of improving the quality of education in Indonesia is becoming more evident. This standard serves as a quality controller and quality assurance as well as a reference for planning, implementation and supervision of education. The 2013 curriculum uses 3 (three) main learning models (Permendikbud No.103 of 2014) which are expected to shape scientific behaviour, social behaviour 
and develop a sense of curiosity. All three models are: the model of Problem Based Learning, Project Based Learning and learning models through disclosure/discovery. Besides the learning model above, a (PBE) Production Based Education learning model can also be developed in accordance with the characteristics of vocational secondary education.

Not all learning models appropriate for all KD / learning materials. Certain learning models are only appropriate for certain learning materials. Conversely, certain learning materials will be able to work optimally if using certain learning models. Therefore, the teacher must analyse the formulation of each KD statement, whether it tends to be Discovery / Inquiry Learning or on learning the work of Problem Based Learning and Project Based Learning.

B. The Distance Learning Standard Model

Regarding learning from home, The Minister of Education and Culture emphasized that online / distance learning is carried out to provide meaningful learning experiences for students, without being burdened with demands to complete all curriculum achievements for class promotion and graduation. Minister of Education and Culture (Education) Nadiem Anwar Makarim issuing Circular No. 4 of 2020 on the Implementation of Education in Emergencies Coronavirus Disease (Covid-19).

Implementation of Learning From Home by the Head of the Education Unit During the emergency period of Covid-19, the head of the education unit took the steps to implement Learning From Home as follows:

1. Determining the management model for educational units during BDR, including:

a. Work and teach from home for teachers and education personnel.

b. Determine the picket schedule if needed. In the event that the picket is carried out, it should coordinate with the education office and the local Covid-19 handling task force.

2. Ensure an affordable learning system for all students including students with disabilities.

3. Make plans for continuing learning. If the Covid-19 emergency period and BDR activities are extended, it is necessary to coordinate teachers to be creative using teaching materials consisting of:

a. Instructions and online learning materials using online media and learning resources.

b. Instructions and offline learning materials using television, radio, books, and students' independent learning modules

c. Instructions for adapting learning materials for students with disabilities.

4. To provide guidance and monitoring to teachers through learning reports that are collected every week

a. Ensure teachers facilitate distance learning both online and offline;

b. Ensure that the lesson plan implements meaningful 
learning, life skills activities and physical activities; and

c. Ensure that there are educational materials for parents / guardians of students related to the prevention of Covid-19 and adopt a clean lifestyle at home.

5. Ensuring the availability of facilities and infrastructure owned by teachers to facilitate distance learning both online and offline during the Covid-19 emergency.

a. Availability of devices/computers/laptops for online learning facilities.

b. Access to online and offline learning media.

c. Distribution of offline learning facilities and teaching aids to students' homes, including educational aids for students with disabilities (for those who do not have access to online learning).

d. Coordinate with the education office, and / or the social service, and/or the women's empowerment and child protection office to make efforts to provide psychosocial support services for educators, parents/guardians, and students. Psychosocial services can use a variety of channels, including:

a) Psychosocial services provided by the National Task Force for the Acceleration of Handling Covid-19 through a call center or call center 119 extension 8; b) Psychosocial services by the Indonesian

Psychological

Association through http://bit.ly/bantuanpsiko logi;

c) Psychosocial services by the Indonesian

Association of Mental Health Specialists http://www.pdskji.org/; and / or

d) Psychosocial services by social workers, contact the local social agency.

e) Creating a parenting program to support parents/guardians in assisting students in learning, at least once a week. The minister of care can be seen on the page

https://sahabatkeluarga.k emdikbud.go.id/laman/;

f) Forming an emergency preparedness team for handling Covid-19 in the education unit, providing briefing on the team's duties and responsibilities, and coordinating with the education office and / or local Covid-19 handling task force and / or the nearest health / referral facility for handling Covid-19.

g) Provide regular reports to the education office and / or related regional education posts:

1. Health condition of the members of the education unit;

2. Distance learning methods used 
(online/offline/a

combination of

online and offline);

3. The number of students who have not been able to be served;

4. Constraints on learning from home implementation; and

5. Good practice and learning outcomes of students.

\section{The Distance Learning Standard Model of EFL Teaching}

Online / distance learning is focused on increasing students' understanding of the corona virus and the Covid-19 outbreak. The learning activities and assignments may vary between students, according to their respective interests and conditions, including in terms of gaps in access / learning facilities at home. Implementation of Learning From Home by the Teacher. The teacher facilitates implementation online, offline, and in a combination of both according to the conditions and availability of learning facilities. a. Prepare a distance learning implementation plan Reference to distance learning planning both online and offline can be seen on the Guru Berbagi portal https://guruberbagi.kemdikbud. go.id/. In preparing for learning, teachers need to ensure the following:

1. Ensure the learning competencies to be achieved. Prohibited from enforcing the completion of the curriculum and focus on life skills education.

2. Prepare learning materials. In implementing learning from home, material can be focused on:

a) Literacy and numeracy;

b) Prevention and handling of the Covid-19 pandemic;

c) Clean and Healthy Living Behavior and Healthy Community Movement;

d) Recreational activities and physical activities;

e) Religious spirituality; and/or

f) Character and culture strengthening.

3. Determine the methods and interactions used in delivering online, offline learning, or a combination of both.

4. Determine the type of learning media, such as text format, simulated audio / video, multimedia, teaching aids, and so on in accordance with the learning method used; and

5. Teachers need to increase capacity by taking online training provided by the 
government and nongovernmental organizations to support skills in organizing teaching distance learning in an emergency situation of Covid-19.

b. Facilitating online distance learning. Online learning times throughout the day adjust to the availability of time, conditions, and the agreement of students and their parents / guardians. The online learning process consists of:

1. Virtual face-to-face via video conference, teleconference, and / or group discussions on social media or messaging applications. In virtual faceto-face ensures direct interaction between teachers and students.

2. (LMS) Learning Management System. LMS is an online integrated learning management system through an application. Learning activities in LMS include registration and account management, mastery of material, completion of assignments, monitoring of learning outcomes, engaging in discussion forums, consultations and examinations/assessments.

Examples of LMS include virtual home learning class, Google classroom, teacher room, Zenius, Edmodo, Moodle, Seamolec LMS teacher, and so on.

\section{Students' Involvement in EFL online Classroom}

From this perspective, developing a high level of student involvement in online learning depends on interaction. In a Melbourne cshe discussion paper in (2020), Michael Moore in Gregor Kennedy, (2020) gives a simple but effect on the taxonomy of the types of interactions that can occur in distance education, which can usefully characterize the various types of student involvement in the online environment: a) StudentTeacher Interaction: The interaction between students and teachers who prepare subject matter, or other experts who act as instructors. b) Student-Student Interaction: This is the interaction between students, between one student and another, alone or in a group setting, with or without the presence of the instructor in real-time. c) Student-Content Interactions: These are interactions between learners and some kind of text or artifact (articles, slides from presentations, audio recordings, etc.) and are often didactic but not exclusively. According to Monica L. Simonsen, (2017) the universal design course for active involvement of students is:

1. Peer to peer interaction.

In terms of student-student interaction and involvement, we can think of peer-based learning, group work, etc. Online discussion forums are typically used in distance programs that should be designed to attract students to respond to specific requests for content, as well as classmates. 'Post. The size of the discussion group, the nature of the questions / discussion prompts, and the type of instructor facilitation has an impact on the level of engagement and quality of 
academic discourse (Kim, 2013).

2. Engaging with instructors.

One of the more influential books in recent decades in the field of educational technology, (Laurillard, 2013) Rethinking University Teaching, presents a conversational framework that proposes interaction, dialogue and feedback between students and teachers (i.e. the studentinstructor interaction above). The heart of education and learning. In very general terms, productive learning occurs when a teacher designs and presents material or activity to students who are then involved by acting and reflecting on it. Learners then respond to the material or activity given their current understanding, often directly to the teacher. This is then reflected and followed up by the teacher before a new round or cycle begins where the teacher can choose to re-present the material or activity, improve or provide feedback to students.

3. Project based learning

Involvement promoted through a pedagogy that requires students issued a collaborative effort to solve the problem (Meyer, 2014). Design courses that enable expression of learning and problem solving to be most effective when considered project-based (Rooij, 2009). One strategy used to ensure students continue progress toward satisfactory completion is by designing an ongoing project, in which students, either individually or in small groups, plan success across multiple points in time with explicit instruction feedback at successive points in time.
In conclusion, based on the theory above the universal design course for active involvement of students promote three types of interaction online: teacher-learner, learner-learner, and learner-content interactions.

\section{Method}

This type of research is descriptive qualitative research in the form of written and spoken words from people and observed behavior (Creswell, 2015). In this study, researchers tried to get close to the subject under study, namely the English teacher and eleventh-grade students at State Senior High School 1 Bengkalis in such a way that the researcher understood what and how they interacted in carrying out the online learning process. This research was conducted on November 25, 2020, until completion. The research location is in State Senior High School 1 Bengkalis district, Riau province Indonesia. The data that will be collected through this research is data that is under the research focus, namely regarding the students' involvement in EFL online classroom during the Covid19 Pandemic era. According to Sugiyono (2011) when viewed from the data source, data collection can use primary and secondary sources. To collect the data the researchers use observation, video documentation, and interview. The data analysis technique used in this study was to use qualitative data analysis techniques developed by Miles, (2019) which included three activities, namely: data reduction, data presentation, withdrawal of conclusions, or verification. 


\section{The Result and Discussion}

\section{A. The Result}

State senior high school 1 Bengkalis applies Learning From Home. Online learning is focused on improving students' understanding of the corona virus and the Covid-19 outbreak. Learning activities and assignments among the students can be different, according to its own condition, including in terms of differential access/learning facilities at home. Based on the researcher's observation, the English teacher facilitates its implementation online in accordance with the conditions and availability of learning facilities. Online learning process consists of a virtual face to face via video conference to ensure direct interaction between teachers and students and (LMS) online learning management system integrated with the application. The following is the school's decision regarding the implementation of learning from home

"Sekolah memutuskan ketika rapat itu menggunakan zoom boleh juga web back namun tidak jugak terlepas dari apa yang ingin guru gunakan tapi wajibnya guru menggunakan zoom dan google classroom karena dari sekolah google classroom untuk penilaian sedangkan zoom untuk proses pembelajaran nya...."

(Interview, SB, 1 December 2020)

Following were the results of observation, video documentation and interviewed about how student involvement in the online teaching and learning process found by researchers in the process of teaching and learning English in the eleventh grade at state senior high school 1 Bengkalis. a. Students' involvement with teacher

Following were the results of observations, video documentation and interview about how the students' involvement and teachers in the online teaching and learning process that the researcher founded in the process of teaching and learning English in class eleven at state senior high school 1 Bengkalis using zoom meeting.

The following were the words of the English teacher during the teaching and learning process.

"Before we continue would you like to share your activities during study at home? What? what you do at home during.. during study at home? You can share your activities at a chat area. Get it now. Please write down your activities."

(Observation, Friday, November ${ }^{\Upsilon}$, r.r. 11::r:00 AM)

Then the English teacher made direct interactions with students in the teaching and learning process in a zoom like the conversation below.

Teacher: Okay, the other come on. Habib worship more, oy worship more? Habib Alfajar? Mana Habib tadi ya?

Teacher : What is that? Habib? Habib? What do you mean by worship more?

Student: Yeah. Apa mom?

Teacher : What do you mean by worship more?

Student: Beribadah mom.

Teacher: What is that? Apa ibadahnya? Mengaji? Read AlQur'an?

Student: Shalat,Praying. Teacher: Yeah, do praying.

(Observation, Friday, November $r$. , r. r. 11:03:55 AM) 
b. Students' involvement with other students

Following were the results of observation, documentation and interview about how the involvement of students and other students in the online teaching and learning process that the researcher founded in the teaching and learning process of English in grade eleven at state senior high school 1 Bengkalis using zoom meeting

The English teacher's statement about student involvement with other students.

"Sebenarnya ada tugas yang diajarkan dengan kelompok tetapi siswa kita ini kan tidak mau tau aturan mereka tetap mengerjakan nya bersamasama. Kalau kelompok ya berarti mengerjakan dirumah temannya. Sudah berkali-kali diingatkan ya ada laporan kesekolah siswa kerjakan dirumah, akhirnya kebijakan dari sekolah tidak ada belajar kelompok yang namanya bekerja kelompok itu ditiadakan."

(Interview, SB, 1 December

The following was the English teacher's statement about how she made students engage with other students.

"Tapi berdasarkan apa yang kita ajarkan seperti speaking itu, sebenarnya tidak murni speaking mereka itu dihaparkan dapat menyimpulkan materi dengan berbicara jadi pemberian tugasnya bisa jadi berbeda-beda bisa dibagi dua yang ini jawab aja punya dia yang ini jawab aja punya dia kemudian ketemukan dizoom jadi Insyaallah menjadi matching tetapi ya soalnya harus dibuat sedemikian rupa tidak menyimpang-nyimpang dasarnya cuma satu ada rujukannya dari mana informasinya sehingga mereka bisa dengan mudah untuk memberikan jawabannya. Itu yang saya buat untuk interaksi, tetapi tidak bisa untuk semua pertemuan tergantung dari pada indicator yang ingin dicapai."

(Interview, SB, 1 December

The teacher asked students to make a conversation about the material being taught, namely "Caption".

Teacher: Untuk IPA 3 dialoge satu yang nomer genap berperan sebagai A. nomer ganjil. tebaleklah biar mudah nomer ganjil berperan sebagai A genap berperan sebagai B. jelas?

Teacher: Untuk IPA 3 nomer absen ganjil berperan sebagai A absen genap berperan sebagai B Jelas dari IPA 3? Halo?

Student: Jelas mom.

Teacher: Oke jelas. IPA 3 yang absen ganjil berperan sebagai A yang absen genap berperan sebagai B. biar mudah mengingatnya ya. Nanti kalau berbicara sebutkan nama teman kamu. Yeah? Halo? Halo halo bandung..

Student: oke mem..

(Observation, Friday, November $r \cdot, r \cdot r \cdot$, 11:03:55 AM)

c. Students' Involvement with Material 
The following were the results of observations and documentation about how students' involvement with the material taught in the online teaching and learning process that the researcher founded in the process of teaching and learning English at eleventh grade of state senior high school 1 Bengkalis by using zoom and Google classroom.

The following is the statement of Mrs. SB regarding the first met of English lessons.

"Biasanya kalau
pertemuan pertama saya
tidak share materinya
karena ingin memancing
background knowlage nya
itu mereka sampai dimana
apakah sudah paham atau
belum. Kalau sudah paham
kita cari apanya mereka
paham engga dengan yang
akan kita ajarkan. Baru
kita kasikan metri yang
berikutnya. Biasanya saya
akan mengajukan LKPG
student worksheet namun
berdasarkan guru belajar
itu kita tidak harus
membebankan siswa
dengan banyak tugas jadi
tidak semua pertemuan itu
ada lembar kerjanya"
(Interview, SB, 1 December 2020)

Then Mrs. SB has given a statement about assigning tasks outside the zoom meeting.

"Walaupun kita tidak boleh membebani kita lihat materinya itu kira-kira perlu tidak tindak lanjutnya? Kalau perlu mengapa tidak. Misalnya belum tercapai belum sampai, mengapa tidak kita berikan penugasan diluar zoom."

(Interview, SB, 1 December 2020)
The following was an explanation of Mrs. SB about how Mrs. SB asked students to use the Google slide application.

"Saya pilih google slide itu bisa dipantau, siapa yang masuk, siapa yang keluar masuk lagi bisa dipantau tapi kalau yang lain misalnya menggunkan tinklink itu tidak bisa di pantau cuman dia sudah menyerahkan tugas belum, begitu saja. Tetapi kalau google slide proses bisa kita lihat dia sedang ngetik apa, siapa yang mengganggu dia. Dan bisa juga untuk interaksinya ada chating nya jadi bisa keliatan."

(Interview, SB, 1 December 2020)

\section{B. The Discussion}

Based on observed data at state senior high school 1 Bengkalis, researchers observed that the activities of the learning process was doing online. Activities and learning assignments among the students can vary according to the condition of each, including differences in access / learning facilities at home. English teacher online facilitate their implementation in accordance with the conditions and the availability of learning facilities.

The principal of state senior high school 1Bengkalis high school gave the decision to all teachers to use two mandatory applications used for the online learning process, namely zoom and google classroom. The online learning process consists of virtual faceto-face via video conferencing to ensure direct interaction between teachers and students using the zoom platform. Then by doing (LMS) an online learning management system that is integrated with the application, namely by using 
the google classroom application. Then the researcher made observations by following the learning process using these two mandatory applications. Here is a presentation data on how the students' involvement in EFL online classroom during the Covid-19 pandemic.

a. Students' involvement with teacher In the online learning process, the teacher plays an important role in controlling classroom conditions. The English teacher at state senior high school 1Bengkalis did several ways to make students interact with him, such as by asking questions directly to students, then the teacher asking students to answer them in two ways. The first is that students can send their answers via chat provided by the zoom application and the second is by providing answer directly in the learning process. However, to make students able to answer the teacher's questions directly is very difficult, because the English teacher has to repeat the questions several times to get responses from students. Of course, this is time-consuming. Meanwhile, the time provided by the zoom meeting is only 30 minutes and the learning process carried out online at SMA N 1 is only 60 minutes for one meeting, this is what makes it difficult for teachers to control their class.

The involvement of students and teachers in the online learning process at state senior high school 1Bengkalis looked a little different from the face-to-face learning process in class. In the eleventh grade online learning process at state senior high school 1 Bengkalis by using this zoom, the teacher take more time to talk and students tend to be passive in the classroom, this is due to factors such as a poor network in the learning process.

b. Students' involvement with other students

In the process of learning English, the teacher is expected to make the class active, namely by making students able to interact with each other in the learning process. However, with the conditions of the Covid-19 pandemic, of course, everything in the learning process must follow government regulations that require all educators and students to study at home.

At state senior high school 1Bengkalis, initially, the principal allowed the teacher to assign assignments in groups to keep students active, work in the learning process, and lighten the student's burden a little. However, of course, it is done online and follows government regulations, but some students at state senior high school 1 Bengkalis did not want to know the rules, if the teacher gives group assignments the students think that they will do the assignment at their friend's house directly. So that a report appeared to the state senior high school 1 that students did not follow the health protocol rules. Due to this, state senior high school 1 Bengkalis determined that teachers were prohibited from giving assignments in groups during the learning process in the era of the Covid-19 pandemic.

However, English teachers certainly do not want to have boring classes because students were passive when learning online. Therefore, the English teacher at state senior high school 1 made tasks in such a way as to be given to students so that students could still 
work and interact with their peers but could not be separated from the lesson time, so that students were able to interact with their classmates in the learning process online even though with a very time-consuming response because the teacher's or student's internet connection network is sometimes bad and interferes with the learning process.

c. Students' involvement with material

The involvement of English students with learning materials at state senior high school 1 can be said to be good. Because the English teacher teach well like how he does face-to-face learning in class. What is different is that he uses an online application. Even though it is done online in the learning process, the English teacher still uses the same teaching method as face-to-face learning, at the first meeting the English teacher did not provide learning material to students because the teacher wanted to see his background knowledge first. The teacher wants to know whether the students understand the topic to be taught or not. If students understand the English teacher wants to know what they understand with the material they understand, and usually the teacher gives students worksheets. However, it does not have to burden students with many assignments so that not all meetings have worksheets.
Then at state senior high school 1 Bengkalis, the teacher got students to be involved with the material being taught using the google classroom application. To find out about the extent of student knowledge, the teacher asks students to do assignments and send them to google classroom. As for the skills of students, the teacher asks students to do assignments using Google Slides. By using Google Slides, the teacher can directly monitor what students are doing. And as for attitude of students, the teacher can see from students who submitted the assignments on time or not.

\section{Conclusion}

Based on the results of the analysis and discussion of the students' involvement in EFL online classroom during Covid-19 pandemic at eleventh grade of state senior high school 1 Bengkalis, The form of students' involvement at eleventh grade of state senior high school 1 Bengkalis are:

First, Students' involvement with teacher were passive

Second, Students' involvement with other students. The students were able to interact with their classmates in the learning process online even though with a very timeconsuming response because the teacher's or student's internet connection network is sometimes bad and interferes with the learning process.

Third, Students' involvement with material. The involvement of English students with learning materials at state senior high 1 Bengkalis can be 
said to be good. Because the English teacher teach well like how he does face-to-face learning in class. What is different is that he uses an online application.

\section{REFERENCES}

Ahsani, E. L. (2020). Strategi Orang Tua dalam Mengajar dan Mendidik Anak dalam Pembelajaran At The Home Masa Pandemi Covid-19. Al Athfal, 3 (1), 37-46.

Creswell, J. W. (2015). Educational Research. United States of America.: Pearson Education.

Euis Kurniati, D. K. (2020). Analisis Peran Orang Tua dalam Mendampingi Anak di Masa Pandemi Covid-19. Jurnal Obsesi: Jurnal Pendidikan Anak Usia Dini, 241.

Haerudin, Cahyani, A., Sitihanifah, N., Setiani, R. N., Nurhayati, S., Oktaviana, V., \& Sitorus, Y. I. (2020). Peran Orang tua dalam Membimbing Anak Selama Pembelajaran di Rumah sebagai Upaya Memutus Covid-19. Universitas Singaperbangsa Karawang, (May), 1-12

Inês Messias, L. M. (2015). Students' engagement in Distance Learning: Creating a scenario with LMS and Social Network aggregation. International Symposium on Computers in Education (SIIE) (pp. 1-6). Lisboa: ResearGate.

Kim, J. (2013). Influence of group size on students' participation in online discussion forums. Computers \& Education, 62, 123-129.

Koran, S. (2015). The Role of Teachers in Developing Learners' Speaking Skill. Conference: 6th
International Visible Conference on Educational Studies and Applied Linguistics, 400-416.

Laurillard, D. (2013). ethinking University Teaching:A Conversational Framework for the Effective Use of Learning Technologies. London and Newyork: Psychology Press.

Meyer, K. (2014). Student engagement online: What works and why. New York: ASHE Higher Education Report.

Monica L. Simonsen, M. E. (2017). Student Engagement in Online and Distance Learning. Ann Arbor: MI: XanEdu.

Naserly, M. K. (2020). Implementasi Zoom, Google Classroom, Dan Whatsapp Group Dalam Mendukung Pembelajaran Daring (Online) Pada Mata Kuliah Bahasa Inggris Lanjut. Jurnal Aksara Public, 4, 155165.

Norziani Dahalan, O. H. (2012). Student Engagement in Online Learning: Learners Attitude Toward E-Mentoring. Procedia - Social and Behavioral Sciences, 67, 464-475.

PERMENDIKBUD. (2016). Standar Proses Pendidikan Dasar Dan Menengah.

Rooij, S. W. (2009). Scaffolding project-based learning with the project management body of knowledge (PMBOK (R)). Computers \& Education, 52, 210-219.

Teguh, M. (2015). Difusi Inovasi Dalam Program Pembelajaran Jarak Jauh Di Yayasan Trampil Indonesia. Jurnal Ilmiah Scriptura, 5, 7178.

Winaya, I. P. (2020). Pendidikan Karakter di Lingkungan Keluarga Selama Pembelajaran 
Idham Syahputra, Nur Isnani - Students' Involvement in EFL Online Classroom during the Covid-19 Pandemic Era

Jarak Jauh pada Masa Pandemi

COVID-19. Cetta: Jurnal Ilmu

Pendidikan, 3, 270-290. 